\title{
The Adventures of Léithin
}

\section{Author(s): Douglas Hyde}

Source: The Celtic Review, Vol. 10, No. 38 (Jun., 1915), pp. 116-143

Stable URL: http://www.jstor.org/stable/30070332

Accessed: 10-09-2016 04:47 UTC

JSTOR is a not-for-profit service that helps scholars, researchers, and students discover, use, and build upon a wide range of content in a trusted digital archive. We use information technology and tools to increase productivity and facilitate new forms of scholarship. For more information about JSTOR, please contact support@jstor.org.

Your use of the JSTOR archive indicates your acceptance of the Terms \& Conditions of Use, available at http://about.jstor.org/terms 


\title{
THE ADVENTURES OF LEITHIN
}

\author{
Douglas Hyde, LL.D.
}

\section{Preface}

I MADE acquaintance with the following story, which so far as I know has never been noticed before, in a rather curious way. Dr. Nicholas O'Donnell, of Melbourne, an Australian born and bred, but a good Irish scholar, picked up some years ago a not very aged Irish MS. in Australia, and kindly sent me a list of its contents. Among other pieces which it contained was 'Eachtra Léithin.' I told him I had not met this story before, and he then and there very kindly made me a transcript of it. I have carefully compared this Australian text with four other copies of this story preserved in the Royal Irish Academy, but I find no virtual difference between them. The oldest copy of the four is by the wellknown southern scribe, Michael $\sigma_{g} \mathrm{O}$ Longan, and was written in 1788. 1 I do not know what MS. he copied from, but in the Australian copy, while the text is practically the same, there is an evident desire on the part of the scribe to keep the story as antique-looking as might be compatible with intelligibility. Hence he appears to prefer to write a long $e$ for ea, as dénamh for déanamh, and nd for $n n$, as lind for linn, etc. The text of the prose as it now stands has been very much modernised. The story, however, in its main features is of considerable antiquity. It is, so far as I know, unique in that it gives us a peep at a whole cycle of bird and beast lore stories now apparently almost lost, but which must have, I think, at one time existed. That

1 23.9.20. The other MSS. (not yet catalogued) are E. V. 5 by Paul O Longáin, written in 1810, 23, P. 18, le William o hogáin as leabhar Eamon ui Mhathghamhna ar na nóidh sgriobha as leabhar Mhichil óig ui Longáin, air na sgriobha an $8^{\text {mh }}$ lá don mhí dá nguirthar Tisri ; aois criost mdcccxxv. 24 A. 3 written by Seumas O Suilliobhain in 1847 (?). 
this was the case is fairly evident from the long Middle Irish poem of 464 lines ${ }^{1}$ preserved in the MS. Egerton 1782 and in the Book of Fermoy: a colloquy between Fintan and the Hawk or Crow of Achill, in which allusion is made to this very story, to the eating of Léithin's two birds, as well as to the death of Blackfoot, the stag who figures here, and of the blackbird, while the whole story of Goll the salmon is told, much as it is told here, and of the crow who robbed him of his eye, the same crow who ate Léithin's birds. That the present text of our story though modernised was, in part at least, taken from older MSS. seems likely. The piece, for instance, about Fintan Mac Laimhfhiadhach and the various shanachies whom God permitted to remain alive to keep account of the genealogies of the world, is found in different words in Leabhar na h-Uidre (cir. 1100). Again the reading of Cluain Feasda, the place to which St. Bearchán is assigned (which in the Australian MS. is still further corrupted to Cluain Fearta), has evidently come from the misreading of some former scribe, who had mistaken an S for an F. ${ }^{2}$ For Cluain Sosta was St. Bearchán's district. He was a renowned saint and prophet, of whom many stories were told.

But perhaps the best proof of the antiquity of the story in its main features is that I have found it told in Connacht as a folk-tale, without any mention of Fintan and his monks, and only as a comparison of ages between the Crow of Achill, the great eagle, the blind trout (not salmon) of Assaroe, and the well-known Hag of Beare. In the folk-tale as told a few years ago by a native of Maltpool, Co. Mayo, the storm and cold which gave rise to the curiosity of the Crow, and its subsequent visits to the other animals, and the loss of the trout's eye, are told pretty much as in our text. I imagine that St. Ciaran and his monks were brought into the tale by some mediæval writer who desired the protection of the

\footnotetext{
1 See Anecdota from Irish MSS., vol. i. p. 24, where the text is printed without a translation.

2 Transliterating $\mathrm{S}_{3}$ ta as Feasta.
} 
Church for this old story, ${ }^{1}$ lest any good friar or cleric might be prompted to say that such tales were folly or superstitions, or were deluding the people; which they would not be likely to assert if the story took place under the ægis, so to speak, of St. Ciaran of Clonmacnoise and his monks, and to the greater glory of that saint. Such devices are common in Irish literature, notably in that great repertoire of all kinds of stories, the Agallamh na Seanórach, where they are told under the protection of St. Patrick himself, and with the sanction of his attendant angel. The incorrect adjective eachlach, too, which is used to qualify the word préachán, is the mistake of some former scribe who, not knowing that Accaill was a place-name (it is a large island off the Mayo coast) with a genitive Accla, made out of the contraction acl an adjective aclach or eachlach; and the fact that the definite article is used before 'préachán' followed by Acla in the genitive is a proof of antiquity, for such a locution as an préachán Acla, though common in Middle Irish, would hardly have been possible for the last few hundred years. $^{2}$

In the old poem in Eg. 1782, a fifteenth century vellum MS., Fintan was himself the salmon. This is one of the many cases of rebirth alluded to in old Irish sagas. ${ }^{3}$

'When the black torrent of the deluge came down, the Creator placed me to my skaith in the form of a salmon on every cold stream,' says Fintan. He frequented the Boyne, the Bush, the Bann, the Suck, the Suir, the Liffey, etc., until he came to Assaroe.

'A night I was on the wave in the north, and I at seal frequented Assaroe. I never experienced a night like that from the beginning to the end of my time. ${ }^{4}$

'I could not remain in the waterfall (pool), I give a leap

${ }^{1}$ It is actually called in one of the MSS. that contains it, 'A story of two monks of Clonmacnoise.'

2 On the other hand, of course, the article may have been inserted by a later scribe, who read aclach or eachlach and thought it an adjective.

3 See Voyage of Bran, vol. ii. p. 80.

' Literally, 'of the world.' 
-it was no luck for me-the ice comes like a blue glass between me and the falls of the Son of Modharn.

' There came a crow ${ }^{1}$ out of cold Achill, above the rivermouth of Assaroe, I shall not hide it though it is a thing to be kept secret, he rapt away with him one of my eyes.

'The Goll or Blind One of Assaroe has clung to me [as a name] since that night. Rough the deed. I am ever since without my eye. No wonder for me to be aged.' 2

The crow or hawk continuing his colloquy with Fintan reminds him of the death of his (Fintan's) own sons ${ }^{3}$ in the Battle of Moytura in Cong, and tells him how he had the picking of them! He tells him of the various battles he had seen in Ireland, and gloats over the reminiscence of the slain. It was he who carried off the hand of Nuadha, which was afterwards replaced by a silver hand, whence the king of the Tuatha De Danann was ever afterwards known as Nuadha of the Silver Hand. He, too, was the crow who perched upon Cuchulain's shoulder, when that great hero was dying. ' I came ${ }^{4}$ above the warrior, as his countenance

1 The word préachan, though it usually means a crow or rook, is applied to the seabhac or hawk in this poem. In the Co. Roscommon I often heard the Marsh Harrier or 'kite,' as they called him in English, termed 'préachán gcearc' in Irish.

2 Adhaigh dhamh ar [in] tuinn túaidh - ocus mé ar Ess rónach Ruaidh,

$\mathrm{Ni}$ fúarus adhaigh mar sain - o thús co deiredh domain.

Tic préchán a hAccuill úair · os cionn inbir Essa Rúaidh · ni biu 'ca chelt cidh fáth rúin . Do fhuadhaigh leis mo lethsúil.

Goll Essa Rúaid do lean dim - ón adhaigh sin, borb a brigh · atú gan mo tsúil o hsoin - nemingnadh dúinn beith arsaid.

3 This is not a mere invention of the poet's. It is recorded that in the first (or southern) battle of Moytura fought between the Firbolg and the Tuatha De Danann, the Firbolg sent for Fintan to take his advice, and that he had thirteen sons in the battle. This story belongs to the mythological or oldest cycle of Irish story-telling.

4 Tanac ós cinn in churad - ocus a drech ar ndubad - d'ithi a súla nír thoisc áigh. crumaim mo chend sa chongháir.

Mothaighis mé ar a agaid - tógbais súas in láim lagaig c cuiris a chletín curad . trem cholainn don chéttulad.

Berim-si eteall angbaid · co h-Inis Géidh dar glennmuir · tairngim assamm, borb an brigh · crann crúaidrighin in chletín.

Anaidh am cholainn in cenn - mo chraidhe do chräidh go tend, $\cdot$ co slán ní iuilimm o hsoin $\cdot \mathrm{s}$ ní cheilim ótú arsaid.

Mé do marb mór na sgéla . jenchorr do bí ar Muigh Léna, ocus ilar Droma. Bricc $\cdot$ do thuit lim 'san ith oirdirc. 
was darkening in death, to eat his eyes. It was not an errand of luck. I stoop my head. . . . He feels me at his face. He raises up his weakening hand. He puts his hero's little quill through my body. . . . I take a troubled flight to Innis Geidh across the valleyed sea, and draw forth from myself, rough the task, the hard, tough shaft of the dartlet. The head remains in my body. It tortured my heart sorely. Sound I am not since that day; and I conceal it not since I am old.

'It was I who slew, great the tidings, the solitary crane that was in Moy Léana and the eagle of Druim Breac, who fell by me at the famous ford.

'It was I who slew, pleasant the supper, the solitary crane of blue Innis Géidh. IT WAS I WHO CHEWED BENEATH MY BEAK THE TWO FULL-FAT BIRDS OF LEITHIN. It was I who slew, royal the rout, THE SLENDER BLACKFOoT of Slieve Fuaid. The BLACKBIRD of Druim Seghsa of the streams died in the talons of my daughters.'

Here are allusions to a whole cycle of bird and beast lore. There were at one time, I should think, stories connected with all of these animals. ${ }^{1}$

Mé do marb súaircc in sére • énchorr Innsi guirm Géidhe · iss mé do chogain fam chír · dá én lánméithi Léithín.

Is mé do marb, righda in rúaig · Dubchosach seng slébe Fúait · lon droma Seghsa na sreb · fuáir bás i crobaib m'ingean.

1 I think I have found the story of the solitary crane of Moy Léana. I discovered a new version of the Agallamh na Seanórach in a seventeenth-century MS., one of the Reeve's collection, which contains a probably thirteenth-century text, and nearly as much again as the texts printed by O'Grady and Stokes. There is in this unpublished text a poem about the crane of the Léana or Marsh, of 584 lines, consisting of a dialogue between the crane and Oisin, in which the crane tells its story. The first two verses begin with the same line, 'a chorr úd thall san léana.' Hence, no doubt, the words 'oénchorr do bí ar Muigh Léna' of the old poem, for the word 'léana' naturally suggested the name 'Magh Léana,' where the great battle was fought whose story forms one of the most famous of Irish romances. The text of the unpublished Agallamh seems to recognise that the crane was already known to Oisin. 'At chí [Oisín] an ccuirr ccrotaigh ccruaidbluirgneach do leath thaobh na conaire 7 tucc aithne fuirre.' He asks her 'cionnas do cuired isin ccoiréacosg sin thú ... oir as imchian o ro choimhriccsiomh rér ccoimhdhíne gos anos.' Her name was Miadhach, daughter of Eachdhonn. She was metamorphosed because she would not give up her lover. As a crane she met with the Eagle of Druim Cró, the Blackbird of Leitir Bile, with whom she falls in love, the Fox of Sliabh Mis, etc. 
It is also obvious that this ancient poem found in Egerton 1782, and in the Book of Fermoy, actually presupposes our story and has a close connection with it. ${ }^{1}$

\section{THE ADVENTURES OF LEITHIN}

A HoLY patron saint, noble and distinguished, there was in the land of Ireland of a time, whose name was Ciaran of Cluan. ${ }^{2}$ A good faith had he in the mighty Lord.

One day Ciaran bade his clerics to go look for thatch for his church, on a Saturday of all days, ${ }^{3}$ and those who were so bidden were Sailmín, son of Beogan, and Maolan, ${ }^{4}$ son of Naoi, for men submissive to God were they twain, so far as their utmost-diligence went, and many miracles were performed for Maolán, as Ciaran said in the stanza :

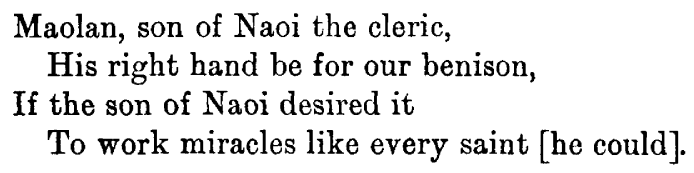

And moreover Sailmín, son of Beogan, he was the same man of whom, for wisdom, for piety, and for religion-he alsoCiaran spake the stanza:

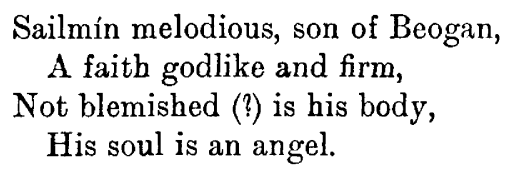

He was the seventh son of the sons of Beogan of Burren, ${ }^{5}$ and those men were the seven psalmists of Ciaran, so that from them is the 'Youth's Cross' on the Shannon, and the [other] 'Youth's Cross' on the high road of Clonmacnoise [named] .

\footnotetext{
1 The pointing of the text, the capital letters, quotation marks, and hyphens are mine. Otherwise I have not interfered with it, except where stated in the notes.

2 i.e. 'Clonmacnois.'

4 These names are not given in any of the Irish martyrologies. 3 Literally 'especially.'

${ }^{5}$ In West Clare.
} 
Howsoever the clerics fared forth alongside the Shannon, until they reached Cluain Dóimh. There they cut the full of their little curragh of white-bottomed green-topped rushes. Thereafter [before they had finished] they heard the voice of the clerics' bell at the time of Vespers on Sunday, so that they said that they would not leave that place until the day would rise on them on Monday, and they spake the lay as follows :

The voice of a bell I hear in Cluan ${ }^{1}$

On Sunday night defeating us,

I shall not depart since that has been heard

Until Monday, after the Sunday.

On Sunday did God shape-out Heaven,

On that day was the King of the apostles born,

On Sunday was born Mary

Mother of the King of Mercy.

On Sunday, I say it,

Was born victorious John Baptist.

By the hand of God in the stream in the East

Was he baptized on Sunday.

On Sunday, moreover, it is a true thing,

The Son of God took the captivity out of hell,

On a Sunday after the battle (?)

Shall God deliver the Judgment of the last day.

On a Sunday night, we think it melodious,

The voice of the cleric I hear,

The voice I hear of a bell

On Drum Diobraid above the pool.

The voice of the bell I hear

Taking me to rest (?)

The voice of the bell I hear

Bringing me to Cluan.

By thy hand, O youth, here, And by the King who created thee, My heart thinks them delightful

Both the bell and the voice.

1 i.e. Clonmacnoise. 
Howbeit the clerics abode that night [where they were] for the love of the King of Sunday. ${ }^{1}$ Now there occurred a frost and a prolonged snow and a rigour-of-cold, and there arose against them bad weather and great rain, and there arose wind and tempest in the elements for their skaith and for their hurt, that it was a misery for all those for whom it had been fated to be placed in a bodily-form and to be that night without the convenience of a bothy or a lean-to of a bed or a fire for them. And surely had it not been for the mercy of God protecting them round about, it was not in the mind of either of them that he would be alive on the morrow after that night, with all they experienced of oppression and terror from the great tempest of that wild-weather, so that they never remembered their acts of piety or to say or sing a prayer (?), nor could they sleep or rest, for their senses were turned to foolishness, for they had never seen the like or the equal of that storm, and of the bad weather of that night, for the venom of its cold and moreover for the bitterness of the morning [which followed it]. And as they were there on the morning of the next day they heard a gentle, low, lamentable woe-begone conversation of grief above their heads on high on a tall wide-extended cliff. And [the meaning] was revealed to them through the virtue of their holiness, and although much evil and anxiety had they suffered [still] they paid attention to the conversation and observed it.

And they between whom the conversation was, were these, namely an eagle who was called Léithin ${ }^{2}$ and a bird of its birds ${ }^{3}$ in dialogue with her, pitiously and complainingly lamenting their cold-state, pitifully, sadly, grievously; and said the bird to the eagle:

'Léithin,' said he, 'do you ever remember the like of

1 A common periphrasis even in modern Irish. See my story of Seághan Tincéar, 'Sgeuluidhe Gaedhealach,' third story, and Religious Songs of Connacht, vol. ii. pp. 272-3.

2 Apparently 'the little grey one' from 'liath'=grey ; pronounce 'Lay-heen.' I have made 'her' feminine and called her 'she' in the translation, but the Irish makes her masculine.

3 i.e. one of its own young eagles or nestlings. 
this morning or of last night to have come within thy knowledge before?'

'I do not remember,' said Léithin, ' that I ever heard or saw the like or the equal of it, since the world was created, and do you yourself remember or did you ever hear of such [weather] ?' said the eagle to the bird.

'There are people who do remember,' said the bird.

'Who are they?' said the eagle.

'Dubhchosach [i.e the black-footed one] of Binn Gulban, ${ }^{1}$ that is the vast-sized stag of the deluge, ${ }^{2}$ who is at Binn Gulban, and he is the hero of oldest memory of all those of his generation (?) in Ireland.'

'Your sin be on you, and your sin's reward. Surely you don't know that, and now although that stag be far away from me I shall go to see him, to find if I may win any knowledge from him !'

Therewith Léithin went off lightly, yet was she scarcely able to rise up on high with the strength of the bad weather, and no more could she go low with the cold of the ... ? and with the great abundance of the water, and though it was difficult for her, she progressed lightly and low-flying, and no one living could reveal or make known all that she met of evil and of misery going to Ben Gulbain looking for the Blackfoot. And she found the small-headed swiftfooted stag scratching himself against a bare oak rampike. And Léithin descended on a corner of the rampike beside him. And she salutes the stag in his own language and asks him was he the Blackfoot. The stag said that he was, and Léithin spake the lay, as follows :

$$
\begin{aligned}
& \text { Well for you, O Blackfoot, } \\
& \text { On Ben Gulbain high, } \\
& \text { Many moors and marshes } \\
& \text { Leap you lightly by. }
\end{aligned}
$$

\footnotetext{
1 Now Ben Bulben in Co. Sligo.

2 i.e. 'as old as the deluge'? I have often met the phrase elsewhere as applied to a great stag. It is a stock phrase, whatever may be the exact meaning.
} 


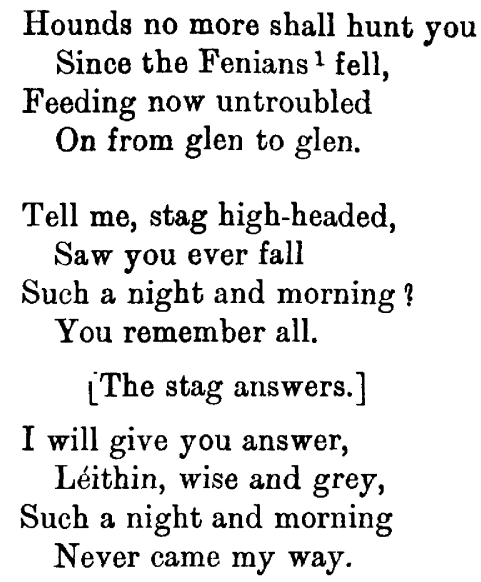

'Tell me, Blackfoot,' said Léithin, 'what is your age ?'

'I 'll tell you,' said the Blackfoot. 'I remember this oak here when it was a little oaklet, and I was born the same year at the foot of the oak that was there, and I was reared upon that couch [of moss at its foot] until I was a mightygreat stag; and I loved this abode [ever], through my having been reared in it. And the oak grew after that till it was a giant oak, and I used to come and constantly scratch myself against it every evening after my journeyings and goings [during the day], and I used [always] to remain beside it in such wise till the next morning, and neither travel nor hot hunting used to affect me, till I used to reach this same tree, so that we grew up with one another, [I and the tree], until I became a mighty-great stag, and this tree became the bare withered rampike which you see, so that it is now only a big ruined maosgán ${ }^{2}$ without blossom or fruit or foliage to-day, its period and life being spent. Now I have let a long period of time ${ }^{3}$ go by me, yet I never saw and never heard tell of in all that time the like of last night.'

Léithin departs [to return] to her birds after that, and

1 The Fenians were the great hunters of game in Ireland in the third century.

2 Decayed wood.

3 The original seems to mean a cargo, [or the people] of five hundred years. 
on her reaching home the second bird spoke to her: 'Have you found out what you went to inquire about?'

'I have not,' said Léithin, and she began to blame the bird for all the cold and hardships she had endured, [but at last] she said, 'Who do you think again would obtain knowledge of this for me ?' said Léithin.

'I know that,' said the bird, 'Dubhgoire [= the black caller] of Clonfert ${ }^{1}$ of Berchán.'

'Well then I 'll go to him.'

And although that was far away from her yet she proceeded until she reached Clonfert of [Saint] Berchán, and she was observing the birds until they had finished their feeding [and were returning home], and then Léithin saw approaching her one splendid bird, beautifully-topped, victorious-looking, of the size of a blackbird, but of the brightness of a swan, and as soon as it came into her presence Léithin asks it whether it was Dubhgoire.

It said that it was.

It was a marvel [to Leithin] when it said that it was, namely, that the blackbird should be white, and Léithin spake the lay.

How is that, O Dubhgoire, sweet is thy warbling, often hast thou paid thy calls throughout the blue-leaved forest.

From Clonfert of the bright streams thou searchest the full plain of the Liffey and, from the plain of the Liffey coming from the east to Kildare behind it.

From that thou wentest to thy nest, in the Cill which Brigit blessed, short was it for thee to overleap every hedge till thou camest to the townland in which Berchan is wont to be.

O Dubhgoire, tell to me-and to count up all thy lifethe like of yesterday morning, did it ever overtake thee, $O$ Dubhgoire ?

[Dubhgoire answers.]

To me my full life was three hundred years before

1 A mistake no doubt for Cluain Sosta, now Clonsast, in Queen's Co. 
Berchan, the lifetime of Berchan I spent [added thereto], I was enduring in lasting happiness.

At one time [with me] was Lughaidh of the blades for a while in the sovereignty of all Ireland, [I remember so much, yet] I never experienced by sea or by land such weather as that which Léithin mentions in his lay. ${ }^{1}$

'Well then, my own errand to thee,' said Léithin, ' is to inquire if there ever overtook you, or if you remember to have seen or [to have heard] that there ever came such a morning as yesterday for badness.'

' I do not remember that I ever saw such,' said Dubhgoire, 'or anything like it.'

As for Léithin she was sad and sorrowful, because her knowledge ${ }^{2}$ was none the greater for this, and she proceeded on her way till she reached her nest and birds.

'What tidings have you to tell us to-day?' said the bird.

'May you never have luck nor fortune,' said Léithin. ' I have none, but I am as I was when I was departing, except all my weariness from all the journeyings and wanderings which you contrive to get me to take, without my getting anything great or small of profit or advantage out of you,' and with that she gave a greedy venomous drive of her beak at the bird, so that she had like to make a prey (?) and flesh-torn spoil of it, with vexation at all the evil and misery she had experienced going to Kildare, so that the bird screeched out loudly and pitifully and miserably.

[A while] after that Léithin said, 'It's a pity and a grief to me if any one in Ireland knows [that there ever came a night worse than that night] and that I myself do not know of it.'

'Well then, indeed, there is one who knows, 'says the bird, 'Goll of Easruadh (i.e. the Blind one of Assaroe), and another name of him is the Eigne ${ }^{3}$ of Ath-Seannaigh (i.e. the salmon of Ballyshannon), and it is certain that he knows about that, if any one in the world knows about it.'

1 Literally, 'I never got on sea or land a knowledge of that lay of Léithin's.'

2 Literally, 'tidings.'

3 This is an old poetic word for a salmon. 
'It is hard for me to go the way you tell me,' said Léithin, 'yet I would like exceeding well to win knowledge about this thing.'

Howsoever she set out, and she never came down until she reached Assaroe of Mac Modhairn, and she began observing and scrutinising Assaroe until she saw the salmon feeding at the pond, and she saluted him and said, 'That is a pleasant [life], $O$ Goll; it is not with thee as with me, for our woes are not the same,' and she spake the lay.

[Léithin speaks.]

'Pleasant is that [life of thine], O Goll, with success (?), many is the stream which thou hast adventured; thou art not the same way as we are. ...

' It is to thee that I have come from my house, $\mathrm{O}$ Blind one of Assaroe; how far does thy memory go back, or how far is thy age to be reckoned?'

[The Salmon answers.]

'As for my memory, that is a long one. It is not easy to reckon it. There is not on land or in bush a person like me--none like me but myself alone !

'I remember, it is no short remembrance, the displacing showers of the Deluge, four women and four men there remained after it in the world.

'I remember Patrick of the pens coming into the land of Ireland, and the Fir Bolg, virile the assembly, coming from Greece to take possession of it.

'Truly do I mind me of Fintan's coming into the country beside me, four men were the crew of his ships, and an equal number of females.

'I remember gentle Partholan's taking the kingship's over Ulster. I remember, a while before that, Glas son of Aimbithe in Emania.

'I chanced to be, one morning that was not fair, on this river, $\mathrm{O}$ Léithin; I never experienced a morning like that, either before it or after it. 
' I gave a leap into the air under the brow of my hard rock [here], and before I came down into my house [of water] this pool was one flag of ice.

'The bird of prey ${ }^{1}$ seized me above the land with a furious ungentle onslaught, and bore away my clear blue eye. To me it was not a pleasant world.'

'Well now, my own object in coming to you,' said Léithin, 'was to inquire of you whether you ever remember such a morning as yesterday was ?'

'Indeed I saw such a morning,' quoth Goll. 'I remember the coming of the deluge and I remember the coming of Partholan and of Fintan and the children of Neimhidh and the Fir Bolg and the Tuatha de Danann and the Fomorians and the sons of Milesius and Patrick son of Alprunn, and I remember how Ireland threw off from her those bands, and I remember a morning that was worse than that morning, and another morning, apart from the great showers out of which the deluge fell. And the deluge left only four men and four women, namely, Noé, son of Laimhfhiach, and his wife and Sem Cam and Japhet and their three wives, for in truth that was the crew of the ark, and neither [church-] man nor canon reckon that God left undestroyed in the world any but those four. Howbeit wise men truly recount that God left another four keeping knowledge and tribal-descent and preserving universal genealogies, for God did not wish the histories of the people to fade, and so $\mathrm{He}$ left Fintan, son of Laimhfhiadhach, towards the setting of the sun, southward, keeping an account of the west of the world, and moreover Friomsa Furdhachta keeping the lordships of the north, and the prophet and the apostle (?) duly ordering the [history of the] south. And these are they who were alive outside of the ark, and I remember all those people, and, Leithin,' said Goll, 'I never saw the like of that morning for venom except one other morning that was worse than the morning that you speak of, and worse than any

1 Literally 'eagle'; but this is a mistake, it was not an eagle.

VOL. $\mathbf{X}$. 
morning that ever came before it. It was thus. One day that I was in this pool I saw a beautifully coloured butterfly with purple spots in the air over my head. I sprang to catch it, but before I came down the whole pool had become one flag of ice behind me, so that [when I fell back] it bore me up on that ice. And then there came the hird of prey ${ }^{1}$ to me, on his seeing me [in that condition], and he made a greedy venomous assault on me, and plucked the eye out of my head, and it was owing to my weight that he was not able to lift me, and he threw the eye into the pool, and we both wrestled together until we broke the ice with the violence of the struggle, and with the [heat of the] great amount of crimson-red blood that was pouring from my eye, so that the ice was broken by that, so that with difficulty I got down into the pool [again], and that is how I lost my eye. And it is certain, O Leithin,' said Goll, 'that that was by far the worst morning that I ever saw, and worse than this morning that you speak of.'

Now as for the clerics they took council with one another [and determined] to await [the eagle's return], that her tidings might overtake them. However, they experienced such hardships and anguish, such cold and misery that night, and they could not [despite their resolution] endure to abide [the eagle's return], so Maolán the cleric said, 'I myself beseech the powerful Lord and the chosen Trinity that the eagle Leithin may come with the knowledge he receives to Clonmacnoise and tell it to Ciaran' [and therewith they themselves departed].

Now as for Goll [the Salmon], he asked Léithin after that who was it that sent her in pursuit of that knowledge.

'It was the second bird of my own birds.'

'That is sad,' said Goll, 'for that bird is greatly older than you or than I either, and that is the bird that picked my eye out of me, and if he had desired to tell you [all] these

1 MSS. reads 'fiolar'=' the eagle,' which is evidently a mistake. 
things it would have been easy for him. That bird,' said he, 'is the old Crow of Achill. And its talons have got blunted with old age, and since its vigour and energy and power of providing for itself have departed from it, its way of getting food is to go from one nest to another, smothering and killing every bird's young, and eating them, and for that reason you will never overtake your own birds alive, and oh! beloved friend, best friend that $I$ ever saw, if you only succeed in catching him àlive on your return, remember all the tricks he has played you, and avenge your birds and your journeyings and your wanderings upon him, and then too mind thee to avenge my eye.'

Léithin bade farewell to Goll, and off she went the selfsame way she had come, in a mighty swift course, for she felt certain [now] that she would not overtake her birds alive, nor her eyrie. And good cause had she for that dread, for she only found the place of the nest, wanting its birds, they having been eaten by the Crow of Achill. So that all Leithin got as the result of her errand was the loss of her birds. But the Old Crow of Achill had departed after its despoiling [the nest], so that Léithin did not come on it, neither did she know what way it had gone.

Another thing, too, Léithin had to go every Monday, owing to the cleric's prayer, to Clonmacnoise. There the eagle perched upon the great pinnacle of the round tower of Clonmacnoise, and revealed herself to the holy patron, namely Ciaran. And Ciaran asked her for her news. And Léithin said she was [not ?] more grieved at her wanderings and her loss than at that. Thereupon Ciaran said that he would give her the price and reward of her story-telling; namely every time that her adventures should be told if it were storm or excessive rain that was in it at the time of telling, it should be changed into fine sky and good weather.

And Leithin said that it was understood by her [all along] that it was not her birds or her eyrie she would receive from him; and since that might not be, she was 
pleased that her journeying and wandering should not go for nothing.

And [thereupon] Leithin related her goings from the beginning to the end, just as we have told them above. So those are the adventures of Léithin, thus far.

$[\mathrm{N}]_{\text {AOMH }}{ }^{1}$ earlamh uasal oireadha ro bhí a ccríoch $\mathrm{n}$-Eireand feacht n-aile dár ba comhainm Ciarán Cluana. Do bhi creidiomh maith aige don choimdhe chomhachtach.

Aon do ló d'fhógair Ciarán da chleirice ${ }^{2}$ dul d'iara[i]dh tuighe chum $^{3}$ na heagluise, dia-sathrainn ${ }^{4}$ go sonradh. Agus as riu adúbhradh sin, eadhon fria Sailmín mac Beogain agus fria Maolán mac Náoi, oir badh lucht umbluigheachta do Dhia an dís sin go nuige a ndithchioll. Agus rinneadh fearta iomdha do Mháolán amhuil adubhairt Ciarán an rann.

Maolan mac Naoi an cléireach

A lamh dheas dár séanadh

Dá madh aill le mac Naoi

Fearta gach naoimh do dhéanamh.

Agus fós Sailmín mac Beógain/fá hé an fear céadna/ar chéill 7 ar chrábhadh agus ar creidiomh/é féin fós, rosbeart Ciaran an rand:

\author{
Sailmín bind mae Beogain \\ Creidiomh diadha daingion \\ Ni h-ainchion a coland \\ $\mathrm{A}^{5}$ anam as aingiol.
}

Gurab é sin an seachtmhadh mac do mhacaibh Beógain Boirne, agus rob iad sin seacht sailmchialluibh Ciaráin, gurab uatha Cros na Macaoimh ar an Soininn, ${ }^{6}$ agus Cros na Macaomh air Slighe Cluana.

1 A large space is left blank in my MS. for the initial N.

2 Thus my MS. ; all the other read ' $d a$ chleireach.'

3 MSS., 'chuin.'

424 A. E. omits from 'dul' to 'sathairn.'

5 E. V. 5 correctly inserts this 'A,' absent in my MS., and in Micheal 0 Longan's.'

6 All the MSS. read 'Soininn.' 
Ciodh trácht ro ghluaiseadar na Cléirig ar fud na Sionna, go rán-cadar go Cluain Dóimh. Bhaineadar lán a ccuracháin do luachair bhuinghil bhár-ghlas ann.

Air sin do chualadar guith cluig an chléiricc a n-am easbarta Dia Domhnaig, go ndubhradar nach fágfaidís an t-ionnad sin go n-éirgeadh an lá Dia Luain ortha, agus adubhradar an laoi mar atá inar ndiaigh,

Guith cluig ad-chluinim a eCluain Oidhche Dhomhnaig co diombuaidh

Ní imeochad ó chualadh súd

Go Luan andeghidh an Domhnaigh.

Dia Domhnaig do d[h]ealbuidh Dia neamh, As ann do rugadh Righ na n-apstal, Dia Domhnaig do rugadh Muire Máthair righ na Trócaire.

Dia Domhnaig adeirim dhe Rugadh Eoin buadha Baiste, Do lámh Déi san $t$ sruith shoir Do baisteadh ē Dia Domhnaig.

Dia Domhnaig fós-as dáil dearbhTug Mac Dei an bhruid a h-ifriond, Dia Domhnaig déis an ágha

Bhēarfas Dia breith an bhrátha.

Oidhche Domhnaig, as bind lind 1

Guith an chleiricc do chluinim, Guith cluig ad-chluinim-se A ndruim Diobraid os an lind.

Guith an chluig do chluinim-se Dom rad-sa go huain, Guith an chluig ad chluinim-se Dom breith-se go Cluain.

Dar do láimh-se a mhacaoimh-se Is dar an righ ${ }^{2}$ ro-d-chruith As ionmhuin leam chroidhe-si An clog is an guith.

1 Thus my MS. ; the other MSS. read 'binn binn' or 'bind bind.'

2 'Rige' or 'righe' in MS. Only 24 A 3 reads 'righ.' 
Acht ro fhansad na cleiricc an oidhche sin ar ghrádh righi an Domhnaigh gur ro fearad[h] sioc agus síor-shneachta 7 róith acus d'éiridh doishinionn 7 mor-fhearaind dóibh 7 ro éiridh gaoth 7 garbhshíon na dúilibh ${ }^{1}$ re a-ndith agus re a ndochar gar mairg doibh da raibh a ndán a ccur a ccolainn, riamh, 7 a mbeith an oidhche sin gan airighthe botha na bélsgatha leaptha na lán tine leo, ann. Doigh ámh muna m-beith trócaire Déi dá n-imdhíon nach raiph an aigne dhuine acu bheith beo air na mháireach déis na hoidhche sin le na bhfuaradar d'éigen 7 d'uathbhás ó mhór-anfadh na garbhshíne sin, go nar chuimhnigheadar ar chrábhadh na caoin-léaghan do rádh na do chantaind, na cotla na comhshuan do dhéanamh, gur ro saobhadh a ccédfadh go na feacadar samhuil na baramhuil do doimhne ${ }^{2}$ ná do dhoishininn ${ }^{3}$ na $\mathrm{h}$-oídhche sin riamh ar nimhnidhe a fuachta agus fós ar ${ }^{4}$ fhuaire na maidne. Agus do bhádar an tráith na maidne air na mháireach go ccualadar an brónchómhrädh ciuin úirísiol éugcaointeach lán-imshíomhach ós a cciond anáirde ar aill phríomhfairsing, gur foillsigheadh dóibh é, tré fertaibh a naomhthachta. Gidh mór d'ole agus d'imshniom do fuaradar tugadar an cómhrádh dá n-uige agus dá n-aire.

Agus as iad do rin an cómhrádh, eadhon fiolar dár bh'ainm Léithín agus éan d'á éanaibh ${ }^{5}$ ag agallamh fria go ciúnlánach gearránach, ${ }^{6}$ aig caoine a bhfuachta go truagh tuirseach imshníomhach, go ndubhairt an t-éan ris an bhfiolar :

'A Léithín,' ar ${ }^{7}$ sé, 'an cuimhin leat macasamhla ${ }^{8}$ na maidne aniugh ná na hoidhche aráoir do theacht ar t'eólas roimhe-si riamh ?

1 All the other MSS. except mine read 'na firmaimente.'

2 All the MSS. read 'doimhne' except mine, which reads 'doimhand.'

3 E. V. 5, omits last five words, and MS. reads generally 'air.'

4 My MS. reads generally, but not always, 'air ' for 'ar.' I have changed it to 'ar' throughout.

$523, G, 20$, and $23, P, 18$ read 'aenda aeinibh.

$624, \mathrm{~A}, 3$ omits these adjectives.

7 'Air' in MS. I have changed to 'ar' in all cases.

8 'Leithéid. 23, G, 20. 
'Ni cuimhin,' ar Léithín, 'go ccuala ná go bhfeaca a samhail ná baramhuil di ó cruthuigheadh an domhan, agus an cuimhin leat féin no an ccuala tú a leithéid ?' air an fiolar ris an éan.

'Atáid daoine le na cuimhin,' ar an t-éan.

'Cia hiad féin ?' ar an fiolar.

'Dubhchosach Binde Gulban,' ar an t-éan, 'eadhon damh diomhór dilean ata ag Bind Gulban, agus asé óglaoch as sine cuimhne da choimhshine féin a n-Eirind é.'

' Ort do chol agus do chol dhuais! dar ndōith níl a fhios sin agad-sa! Gidheadh, ciodh fada sin uaim-se, rachad dá fhéachuin an bhfaghaind scéla uadha.'

And sin gluaiseas Léithin roimhe go himéd[t]rom, agus nochar bfhéidir leis eirge go hárd le neart na garbhshine, agus ní mó fhéad go hísiol le fuacht na fiodhbhuidhe agus le h-il-iomad an uisge, agus gé ar dheachair do é ro ghluais, go h-im-éd[t]rom in-ísiol, agus nochar ${ }^{1}$ bhfëidir le neach ar bith a fhaisnéis ná a innsin a bhfuair d' olc agus d'anró ag dul go Bind Gulbain aig iarra[idh] Dubhchosaig[h]. Agus ro fuair an damh ceand-bheag cos-luath da thochas féin re fiodhlomán daruidhe, gur thúirrlind ${ }^{2}$ Léithin ar bind don lomán mail[1]e ris, agus beannuigheas don damh tré a urlabhra féin, agus fiafruigheas de ar bh' é Dubhchosach é. Adubhairt an Damh gurbh'é ; agus do bheart Léithin an laoi, mur atá :

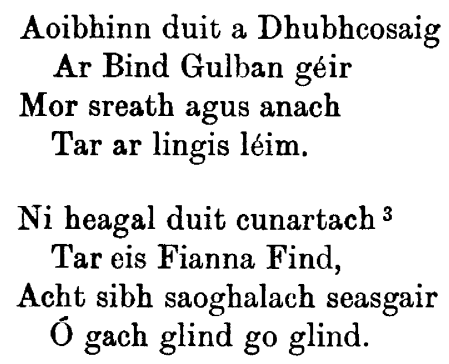

\footnotetext{
1 'Noch air,' MSS.

2 Thus my MS. ; all the other MSS. read 'túrn' except 23, G, 20, which is not clear.

${ }^{3}$ My MS. and O Longan's, 23, G, 20, and E. V. 5 read 'cuanartach. 24, B, 12, reads as in text.
} 


\author{
Abair liom a Dhubhchosaig \\ A dhaimh cind ar chaoimh, \\ Macasamla na maidne-se \\ Cuimhin ${ }^{1}$ do rála dhibh. \\ [Dhe Damh ag freagairt.] \\ An cheist do chuiris-se \\ A Léithín ghloin ghaoith \\ Mac samhla na maidne-se \\ Cuimhin rala dhiobh. ${ }^{2}$
}

'Innis dam a Dhubhchosaigh,' 3 ar Léithín, 'créad as
aois duit ?'
'In[n]eósad,' ar Dubhchosach, ' eadhon as cuimhin liom
an [crann] darach so shíos do bheith ionna darachán óg : Agus aon bhliaghain do rugadh mise a mbun na darruighe so bhi and, agus ro hoileadh mise ar an leabadh so no gur dhamh diomhór mé; gur charas an adhbhadh so tream oileamhuin uirthe; gur fhás an dair iar sin go raibh na [dhair ?] mhóir, ${ }^{4}$ agus do thigind-se dam' ghnáth-thochas

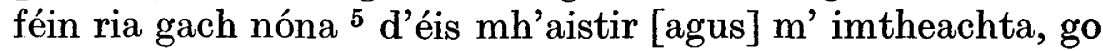
bhfanaind aici fá'n n-iondbuidh sin go maidion ar na mháireach. Agus nocha ccuireadh ${ }^{6}$ taisdiol, ná tromfhiadhach orom go soichinn an crann cétna, gur fhásamair ri aroile, ${ }^{7}$ go ndearnaidh damh díomhór díom-sa agus lomán lom lán-chrion do'n chrand so ad-chidh-se ; go bhfuil na mhaosgán mhór mhadhmtha gan bhláith gan toradh ná duillemhar aniugh iar ccathamh a rae agus a shaoghail. Ciodhtrácht do chuirios lucht chüig céad bliaghan do leath díom. Gidheadh ni fhaca agus ní chuala ris an rae sin ionnshamhuil na hoidhche araoir.'

Gluaiseas Léithín roimhe, d'iondsuighe a éan, agus ar

1 Thus my MS.; the others read 'cuín,' perhaps ' cathain,' 'when.'

2 All the MSS. read thus, senselessly, which shows they are descended from the same recension, the original scribe of which wrote this line twice by mistake.

3 Dubhchosach and Dubhcosaig MSS.

4 All the MSS. read 'go raibh na mhóir,' but this locution seems strange.

5 My MS. reads 'neóna.'

${ }^{6}$ My MS. and 23, P. 18, read 'a ccuireadh. Neither reading is clear.

${ }^{7}$ Ria ar oile, MSS. 
rochtain chum baile do, adubhairt an dara héan ris 'An bfuairis fios ná fuasgladh an sgéil um a ndeachais ?'

'Ní bfuaras,' ar Léithín, agus ro ghabh ic im-chasáoid ar an éan tré n-a bhfuair d'fuacht agus d'anró, go ndubhairt ' cia aige a saoilfea a fhios d'fhághail dam anis ?' ar Léithín.

'Atá' fhios sin agam,' ar an t-éan, 'Dubhghoire, eadhon lon Chluana Ferta ${ }^{\mathbf{1}}$ Bearacháin.

'Maiseadh rachad d'á iondsuighe.'

Agus gér bhfada sin uaidh do ghluais roimhe no go rainig Cluain Ferta Bearacháin, agus ro bhi $[\mathrm{ag}]^{2}$ feithiomh na n-éanlaithe no go rainig leó sgur d'á n-innillt, go bfeaca Léithín aon éan bardha bárr-áluinn bioth-bhuadhach dá iondsuighe go méad loin agus go ngile eala. Agus iar tteacht chum láirthig do, fiafruigheas Léithín de 'ar bh'é Dubhghoire é.'

Adubhairt-sion gur bh' é.

Ro ba iongna iar na h-insin gur bh' é, eadhon an lon do bheith gléigeal, go ndubhairt Léithín an laoi.

Cionnas sin a Dhubhghoire

Binn air do longhaire,

Minic chuiris cuardaighthe

Ar feadh fedha gormdhuille.

Ac Cluan ${ }^{3}$ Ferta na sreabh mbán

Sire Mágh Life lomlán,

O Mágh Life ag teacht anshoir

Go Cill-dara na dheghaidh.

As sin duit-se chum do neid

A ccill do bhennuigh Brighit,

Gairid duit léim tar gach fál

Gus an mbaile a mbí Berchán.

A Dhubhghoire innis dam

Do shaoghal iomáireamh

Macasamhla na maidne anae

An ttarthaidh tú a Dhubhghoire.

\footnotetext{
${ }^{1}$ E. V. 5 reads 'Chuan Feasta,' so does 24 A. E. and 23, G. 20. But Cluain Sosta was probably the original reading.

${ }^{2}$ All the MSS. omit 'ag,' which is often omitted in folk speech, but seldom in MSS.

${ }^{3}$ Probably 'a cluain,' i.e. 'from Clonfert' is the right reading, but all the MSS. read as in text.
} 
[DUBHGOIRE AG FREAGAIRT.]

Damh-sa sin badh saoghal slán

Tri cét bliadhan roimh Bearachán

Saoghal Bearachán do chaithios

Do bhios buan a mbith-mhaithes.

A n-aon aimsir do bhí Luighidh ${ }^{1}$ na lann

Sel na rigi ar Eirind,

Ni bhfuaras ar muir nó ar tír

Aithin na laoi ${ }^{2}$ sin a Léithín.

'Maiseadh as í mo thoisg féin chugad-sa,' ar Léithín, ' $d a$ fhiafruighe díot an ttárthaidh tú no ar cuimhin leat leithéad na maidne anae do theacht na dfaicsin riamh ar a holcas ?'

'Ni cuimhin liom go bhfeaca,' ar Dubhghoire, 'na fós baramhuil dí.'

Dála Léithín do bhí go doilg[i] dobronach oir níor liaide ${ }^{3}$ a sgéala sin, agus gluaiseas roimhe go ráinig a nead agus na héain.

'Ca sgéala agad aniugh ?' ar an t-éan.

' Nár ba soirbh na sona dhuit-sc choidhche,' ar Léithín, ' ni bhfuilid sin agam, acht mar do bhádhas ag imtheacht dam, acht amháin mēad mo thuirse ó gach siubhal agus aistear da ttig díot-sa dhéanamh dam, gan a bheag ná [a] mhór dod thairbhe ná dod $\mathrm{t}[\mathrm{h}]$ oice dfhághuil dam '_- go dtug sidhe sanntach, sár-nimhneach d'á ghulbán chum an éin, gur fhobair aghaidh fhoghladh agus fheólsgasilte ${ }^{4}$ do dhenamh de, le h-aingideacht ó na bhfuair d'olc agus d'annro, ag dul go Cilldara,-gur sgréach an t-éan os árd go trom tuirseach êagcaointeach; go ndubhairt Léithín air sin. 'As truagh agus as doilg liom má atá a fhios a n-Eirind ag aon duine, gar a fhios agam féin.'

'Maiseadh go deimhin atá,' ar an t-éan-ag Goll Easa-

1 Laigh, 23, G. 20 ; the others read as in text.

2 Thus E. V. 5 and 24, A 3. My MS. reads 'laoidhe.' The ' $a$ ' is omitted in my MS. and another. The correct reading was probably 'aithin na laoi-se a Léithín.

3 Thus 23, G. 20. My MS. reads 'liaidhe.'

So all the MSS. read. Some do not aspirate the f of feólsgaoilte. 
ruadh, agus ainm eile do Eígne Átha Seannaigh; agus is dearbh go bhfuil a fhios súd aige má tá san domhan a fhios.'

'Deacair liom imtheacht ar t'eólas,' ar Léithín, 'agus ${ }^{1}$ ro ba mhaith liom a fhios súd d'fághail.'

Gidheadh ro ghluais roimhe agus níor thúirling ${ }^{2}$ go ráinig Easruadh Mac Modhuirn, gur ghabh ag breithniughadh agus ag mion-fhéachain na hEasa uaidh, go bhfeaca an t-éigne ag innilt for san ath, gur bheannaidh do, go ndubhairt ' sádhail sin a Ghoill, ní h-ionnan sibh agus sinne, oir ní hionand galar dúinn, agus adubhairt an láoi.

\section{[LÉrthín]}

Sádhail sin a Ghoill go ngráin Mo ${ }^{3}$ sruith a ndeachais na dáil, Ní hionand sibh agus sinne Siubhalach orm da indsin.

As chugad tánag óm' thig A Ghoill Easaruadh rómhaig, ${ }^{4}$ Cáidhe do chuimhne go ccionn No cáidhe h'aois re h-áireamh? [GOLL AG FREAGAIRT]

Mo chuimhne, as fada soin Nocha hurasa a h-áiriomh, Ní bhfuil ar talamh ná a toror Neach amhla acht mé am' aonar.

As cuimhin liom, ní cuimhne gearr, ${ }^{6}$ Ceatha ${ }^{7}$ diothchuir na dileand. Ceathrar ban is ceathrar fear Ro bhí ionna ndiaig san domhan.

\footnotetext{
1 Even in modern Irish one often finds 'agus' written where one would rather expect 'acht.'

2 All the MSS. except nine read 'thúrñ.'

3 This is a dialectic Munster form of 'iomdha.'

${ }^{4}$ So in E. V. 5, but 'ró mhoig' in my MS., and 23, P. 18, and in 23, G. 20. 'rónach,' i.e. 'full of seals,' is the adjective applied to Assaroe in the old poem of the Hark of Achill. This may be a corruption of it.

5 'Na a ttor,' E. V. 5. The other MSS. omit the 'a.'

6 MSS. 'géar,' but this does not rhyme with 'dileann.'

7 'Catha' MSS. But this is evidently incorrect, for the prose reproduces the word 'ceatha' which makes sense.
} 
Cuimhne liom Pattruig na ${ }^{1}$ bpeann

Do theacht a ttír n-Eireand

Is Fir Bolg, feardha an dáil,

Do theacht ơn nGréig da gabháil.

Fiondtainn as fiorchuimhne liom

Do theacht sa tír-se láimh liom, ${ }^{2}$

Ceathrar fear lucht a loinge

Sa ccoimhlion do bhanchoire.

Cuimhne liom Parrthalan cáin

Do ghabháil righe ar Olltuibh,

Cuimhin liom seal roimhe sin

Glas mac Aimbithe a n-Eamhuin.

Tárla mé maidionn nár mhín

Ar an abhainn-se a Léithín,

Ní bfuaras maidiond mar sin

Riamh roimpe ná na deghaidh.

Do rugus léim anáirde

Fa ceannaibh mo chruadh-chairrge,

Sul do thúrnas dam thig

Do bhí an lind na lic oidhridh.

Rug orm an fiolar os tír

Sídhe anfadhach ainmhín,

Do rug leis mo rosg gorm-ghlan

Damh-sa níor shoirbh an saoghal.

'Maiseadh así mo thoisg féin chugad,' ar Léithín, 'dá fhiafruighe díot an cuimhin leat leithead na maidne anaé ?'

'Do chonare go dearbh,' ar Goll, ' as cuimhin liom teacht na dílinde, agus as cuimhin liom teacht Parrtholáin 7 Fionntaind, 7 chlanna Neimheadh 7 Firbolg 7 Tuatha De Danann ${ }^{3}$ agus Foghmoraigh agus maca Mileadh 7 Pattruic mac Alphruind, agus as cuimhin liom gur chuir Eire na diormadh sin di, agus is cuimhin liom maidionn badh mheasa na'n mhaidion sin, agus maidionn eile a n-ēagmus an mhór-cheatha dár' thuit an Dilend. Agus níor fhág an díle acht aon cheathrar amháin fear agus ceathrar ban, eadhon Noe mac Laimhfhiadhach 7 a bhean 7 Sem Cam agus Japhet a thriúr ban: gurob iad sin lucht na h-airce go deimhin.

1 The 'na' added from E. V. 5 and 23, A, 3.

2 Thus in the other MS. My MSS. reads 'bhláith úir.'

3 All the MSS. read 'deanainn' or 'deanaind.' 
Agus ní áirmhionn duine ná canóinn gur fhág Dia duine ar domhan gan díothughadh acht an t-ochtar sin. Gidheadh áirmhíd eoluigh[h] go fírinneach gur fhág Dia cethrar oile ag comeud eóil agus cineóil agus ag gabháil geinealaigh cómhchoitchiond, óir nior bh'āil le Dia sgēla na ndaoine do dhithcheal $a d h$, agus ro fhág Fiontainn mac Laimhfhiadhach ${ }^{1}$ re fuineadh na gréine teas, ag coiméad feasa iarthair an domhuin, agus fós Friomsa Furdhachta ag coiméad tighernais an tuaisgirt, agus an faidh agus an t-easbadh, ${ }^{2}$ ag deaghordughadh an deisgirt, agus asiad sin do bhí beó a n-éagmuis na $h$-áirce, gur cuimhin liom-sa an lucht sin uile, a Léithín,' ar Goll, 'agus ni fheaca samhuil na maidne sin ar a h-olcas acht aon maidiond amháin badh mheasa 'ná'n mhaidionn sin a deire-si, agus 'ná gach maidiond d'á ttáinig riamh roimpe: eadhon lá n-aon dá rabhas-[s]a ar an lind-si, go bhfeaca eitiolachán ${ }^{3}$ niamh-dhathach ball-chorcra os mo chiond anáirde, gur lingeas da ionnsuighe, agus sul thúirling mé do rinne ${ }^{4}$ áoin-leic oidhridh don lind uile, tar mh'éis, ${ }^{5}$

1 This seems a reminiscence of the curious fragment at $f$. 120, . b . line 30, of 'Lebor na h-uidre,' which, so far as I know, has never been printed before :

Fintan mac Bocra mac lamíach is é in tres fer tánic in erind ria ndilind. Is eside ro chomet senchasa iarthair in betha . 7 . Espain 7 in Eirind 7 in cach conair do deochator goédil ar chena. . 1 . bliadain re ndilind 7 . u . c. 7 u. mbliadna iar dilind a aes conerbailt ac dún Tulcha. Féren mac sisten mac Iafed mac Nóe isé ro chomét senchas tuascirt in betha iar dilind otha slebi Rip atuaid, etc. . . Fors. mac Electra míc Seth mic Adaim isé ro chomhet senchas asarda o muir Fors in golgotha, etc. ... The fourth Shanachie was 'Annoit mac Ethioir,' etc. Is iat sin in cethror ro chomet senchas in betha_ The tract ends unfinished, the next page being lost.

Translation.

Fintan son of Bocra, son of Lamech, he was the third man who came into Ireland before the deluge; it was he who kept the histories of the west of the world, namely, Spain and Ireland, and moreover the history of each road which the Gaels went. Fifty years before the deluge and five hundred and five years after the deluge was his age when he died at Dún Tulcha. Feren mac Sisten, son of Japhet, son of Noah, it was he who kept the history of the north of the world after the deluge from the Riphean mountains north, etc. . . . Fors, son of Electra, son of Seth, son of Adam, it is he who kept the Assyrian history. . . . These are the four who kept the history of the world.

2 So in my MS. 24, A 3 reads 'an tseab.' 23, G. 20 reads easb, perhaps 'easbal' or 'easbog' is the right reading. The name of the faidh has evidently dropped out.

323 , G. 20 reads 'eitioldn.'

- In modern Irish, especially in parts of Munster, this 'rinne' has a passive sense as here, i.e. 'was made,' 'turned into,' or 'becamo.'

- MSS. read 'tairmhéis.' 
gur ro chongaidh mé for san oidhridh sin, go ttainig an fiolar dom' ${ }^{1}$ ionnsuidhe ar mo fhaicsin do, go ttug sidhe sanntach sár-nimhneach orm, gur bhain súil ${ }^{2}$ as mo cheann. Agus ro badh do m' thruime nár fhéad mé thógbháil, gur theilg an tsúil fá'n lind, agus ro chuireamar araon sparuind re chéile gur bhriseamair an t-oidhridh le spreoighiocht ${ }^{3}$ na sparuinne sin, agus le hiliomad na fola flann-ruadh ag teibiorsan óm' shúil-se, gur briseadh an oidhridh de sin, go ndeachas-a fá'n lind ar éigin, gur chailleas mar sin mo shúil, agus as dearbh a Léithín,' ar Goll, ' gur b' í sin aon mhaidion as measa go mór da bhfeacas-a riamh, occus as measa 'ná an mhaidiond sin adeir tusa.

Dála na ccléireach do chomharlighedar re chéile go bhfanfaidis re sgéala do bhreith ortha. Gidheadh fuaradar an oiread san d'olc agus d'annró d'fhuacht agus d' imshníomh an oidhche sin nar fhéadadar fullang re fuireach. Agus adubhairt Maolán an cléireach 'guidhim féin an Coimhdhe comhachtach agus an Trionóid toghuidhe go ttig an fiolar, eadhon Léithín, leis an sgéal do geabh, go Cluain, da innsin do Chiarán.'

Dála Ghoill, air sin ro fhiafruig do Léithín cia chu[i]r ag iarraidh na sgéal sin é.

'An dara h-éan do m'éanaibh féin.'

'As truagh sin,' ar Goll, 'as mó gur sine é sin ná tusa 7 'ná mise leis. Agus ag sin an tí bhain mo shúil asam-sa, agus da ma[dh] áill leis na sgéala d'innsin duit-se as dō badh usa é, agus ${ }^{4}$ asé $\sin$ an sean-phréachán Eachlach. ${ }^{5}$ Acus ro mhaoluighedar a ingne le h-ársuigheacht, gurab é as beatha dhó ó chuaidh a lúith 7 a lámhach agus a shalāthar féin as, eadhon bheith ó gach neid go chéile ag múcha[dh] agus ag marbhadh ealta gacha héin, agus aga ttumailt. Agus da bhrigh sin ní bhéara tusa beó ar h'éanuibh féin. Agus a

1 MSS. read 'dam.'

20 Longan and 23, P. 18, contract this word thus $\odot$.

$323,9,20$ reads 'spreóingeacht' so far as I can decipher it. $24, \mathrm{~A} 3$ and E. V. 5 read 'spreónghiocht.' $23, \mathrm{P} .18$, reads as in text.

4 'As' MS. (?) 'mbreireadh ' read 'de mbeire tusa beó air,' all MSS.

5 Recté 'Acla.' 
charuid ghrádhach as feárr do chonarc riamh, da mbeireadh ${ }^{1}$ tusa beó air, dhul tar ais cuimhnigh ar imir sé ort, agus díoghail na héain agus t'aisdior agus do thuras air, agus fós cuimhnigh mo shúil do dhíoghail air.'

Ceileabhras Léithín do Gholl 7 gluaisios roimhe a bhfrithin na conaire cétna, in a réimib ro luatha, oir badh deimhin leis na béaradh beó ar a éanaibh na ar [a] adhbhadh.

Agus ro bhí adhbhar na hegla sin aige, óir ní bhfuair acht áit na neide, ar dith a éan, ar n-a n-ithedh do'n phréachán Eachlach. Go nach fuair Léithín do tharbha a thosga acht easbadh a éan. Agus ro imthig an sean-phréachán Eachlach d'éis na foghla sin do dhénamh go nár rug Léithín air. Agus ní mó do fheidir cá conaire ina ndeachaid.

Nídh eile fós, do b'éigin do [Léithín] dul gach Luan tré ghuidhe an chleirice go Cluain. Do ${ }^{2}$ chuaidh an Fiolar ar bind mhór chluig-tighe Chluana, gur fhoillsigh é féin don Naomh éarlamh, eadhon Ciarán, go raibh ag fiafruighe sgéala dhe. Agus adubhairt Léithín gur ${ }^{3}$ dhoilge leis 'ná sin an imtheacht $\eta$ a dheacair féin.

Annsin adubhairt Ciarán go ttiubhradh logha agus sochar a sgéaluigheachta do, edhon gach uain do h-inneósdaoi a eachtra da madh doisoineann no fearthaind díomhór do bhiadh an tan sin ann, a thurnamh a soininn agus a so-aimsir.

Agus adubhairt Léithín gur ro thuigeadh do nách iat na h-éain na an adhbhadh do gheabhadh uadha, agus ó nách iat, gur mhaith leis gan a thuras ná [a] aistear do dhul a n-aisge. Agus innisios Léithín a imthechta ó thús go deireadh, ${ }^{4}$ amhuil adubhramair reómhaind. Gonab í sin Eachtra Léithín, go nuige sin.

\section{CRÍOCH.}

\footnotetext{
1 'Da mbreireadh (sic) ortsa beó' my MS.

2 MSS. read 'mar,' which seems awkward.

3 One would expect 'nár,' or else to read 'gur dhoilge leis sin "na" a imtheacht, etc., fein.

4 All the MSS. except mine add here the words 'gur sgribomur mar a fuuramar reómhainn iad acht muna ndearnamar focal dearmaid.'
} 